\title{
Mucinous Breast Carcinoma
}

National Cancer Institute

\section{Source}

National Cancer Institute. Mucinous Breast Carcinoma. NCI Thesaurus. Code C9131.

An invasive adenocarcinoma of the breast characterized by the presence of islands of small and uniform cells, surrounded by large amounts of mucin. Pure mucinous breast carcinomas generally have a favorable prognosis. 